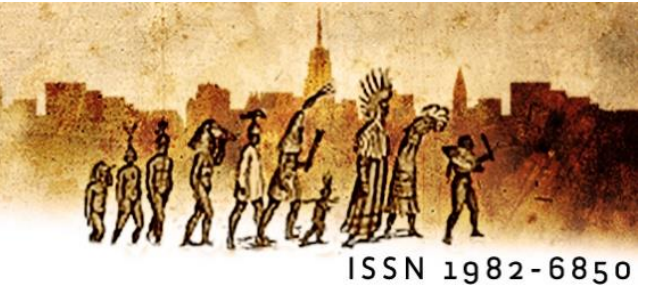

\title{
Fazendo água, poética da imersão de Jorge Wanderley
}

\section{The hull is taking water, immersion on Jorge Wanderley's poetry}

\author{
Mario Newman de Queirozi (UFRRJ)
}

Que assim não finde a rosa da beleza

Shakespeare para Jorge Wanderley

\begin{abstract}
Resumo: Este artigo busca tornar evidente, através sobretudo da leitura analítica de três poemas, como a poética de Jorge Wanderley constrói uma subjetividade singular por refutação ao individualismo, e por imersão na tradição poética. Para isso é preciso consolidar a tradição como um campo transcendental, solo vivo e atual, em que a voz que se manifesta nos poemas busca paradoxalmente o seu apagamento, em frontal recusa ao individualismo moderno e suas presunções.

Palavras-chave: Jorge Wanderley; Poesia Brasileira; Poesia e Singularização; Produção de Subjetividade.
\end{abstract}

\begin{abstract}
This article seeks to highlight, mainly through the analytical reading of three poems, how Jorge Wanderley's poetics builds a singular subjectivity by refuting individualism, and by immersion in the poetic tradition. Thereunto, it is necessary to consolidate the tradition as a transcendental field as a living and current soil, in which the voice that manifests itself in the poems paradoxically seeks its erasure, in a frontal rejection of modern individualism and its presumptions.

Keywords: Jorge Wanderley; Brazilian Poetry; Poetry and Singularization; Production of Subjectivity.
\end{abstract}

\section{Introdução}

\footnotetext{
${ }^{1}$ - Segundo verso do Soneto 1, in: SHAKESPEARE, 1991, p. 33.
} 
Na apresentação de si, que a voz dos poemas de Jorge Wanderley faz, há duas figuras de profissional: o médico e o tradutor. As duas coincidem com a biografia do autor, mas seria isso biografismo? Por biografismo compreendemos a tendência na modernidade de um autor (de literatura, artes plásticas, cinema, música...) reforçar através de sua obra as referências a si mesmo, não deixando a obra escapar da formulação de uma imagem do próprio autor, obras de autoreferência constante. Tzvetan Todorov, in "Poderes da poesia", chama atenção para essa vertente forte na literatura contemporânea, a miná-la por dentro, a que denomina de tendência "solipsista".

Essa prática literária provém de uma atitude complacente e narcísica que leva o autor a descrever detalhadamente suas menores emoções, suas mais insignificantes experiências sexuais, suas reminiscências mais fúteis: quanto mais repugnante é o mundo, mais o si mesmo é fascinante! Falar mal de si, aliás, não destrói esse prazer, já que o essencial é falar de si - o que se diz é secundário. (TODOROV, 2012, p. 21)

Deve-se destacar que essa é uma ocorrência talvez exclusiva das artes na modernidade, principalmente a partir do início do século $X X$, da imagem de sujeito que a modernidade cria a partir dos séculos XVII e XVIII no ocidente. Foucault já em $O$ nascimento da Clínica observava que a medicina moderna, a morte como finitude, e o indivíduo moderno se enlaçam e se sustentam desde seu nascimento uns nos outros e numa prática de tudo trazer à luz do discurso: "uma relação obstinada com a morte prescreve ao universal sua face singular e dá à palavra de cada um o poder de ser indefinidamente ouvida; o indivíduo lhe deve um sentido que nele não se detém" (FOUCAULT, 2003, p. 227). A estratégia do poder nas sociedades modernas, a que chama "disciplinares", age de uma forma por demais astuta, o poder longe de nos impedir a fala, estimula a que falemos, por exemplo, de sexo, que coloquemos o sexo em discurso, e nisso acreditamos estar nos liberando de alguma repressão, mas assim estamos obedecendo às determinação dos dispositivos de poder. Cada vez mais o diário antes secreto se torna declaração em rede social. E o falar de si como a trazer-se voluntariamente à luz do panóptico, a servir voluntariamente às estratégias do poder, definir-se, definir-se no mais alto grau, nos mínimos detalhes do cotidiano e da vida privada, eu sou isso, eu sou assim, eu sou... Foucault aponta para uma "troca do eixo 
político da individualização" (2002, p. 160) opondo o poder e a individualização na idade média e a partir da idade moderna.

Nas sociedades de que o regime feudal é apenas um exemplo, podese dizer que a individualização é máxima do lado em que a soberania é exercida e nas regiões superiores do poder. Quanto mais o homem é detentor de poder ou de privilégio, tanto mais é marcado como indivíduo, por rituais, discursos, ou representações plásticas. (...) Num regime disciplinar, a individualização, ao contrário, é "descendente" à medida que o poder se torna mais anônimo e mais funcional, aqueles sobre os quais se exerce tendem a ser mais fortemente individualizados; e por fiscalizações mais que por cerimônias, por observações mais que por relatos comemorativos, por medidas comparativas que têm a "norma" como referência, e não por genealogias que dão os ancestrais como pontos de referência; por "desvios" mais que por proezas. (FOUCAULT, 2002, p. 160-161)

Há isso na poesia de Jorge Wanderley, o reforço da imagem de um eu aos moldes do individualismo moderno, a partir de referências autobiográficas? Há essa servidão lacaia se achando especial, a que se presta aquela que Todorov chama de tendência solipsista da arte? É preciso uma ausculta aos diversos nomes de poetas e autores constantemente evocados e citados nos poemas. É preciso auscultar a poesia de Jorge Wanderley em busca de resposta. Na brevidade deste artigo, faremos a análise de três poemas de uma fase já, conforme João Alexandre Barbosa (BARBOSA, 2001, p.19), madura do poeta em busca de respostas que nos tragam um pouco de sua poética.

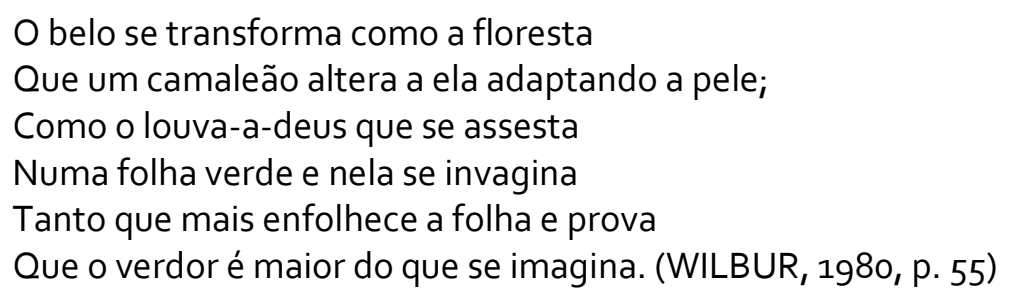

\section{O médico e o tradutor}

A dupla identificação de médico, neurocirurgião, e tradutor está presente no corpo de muitos poemas de Jorge Wanderley. A persona de médico e a medicina aparecem, p.e, em expressões: "Minha casa; São Paulo; a medicina." (1986, p. 8), "altamente cirúrgico" (1986, p. 10), "'Acadêmicos' de medicina" (1986, p. 26), "praticar saúde dos outros" (1986, p.53); "Livros-tijolos medicinais" (1986, p. 83). A persona 
tradutor, talvez seja mais difusa, mais espalhada, mas de contornos menos nítidos. Se nos atermos aos poemas de Jorge Wanderley ele mesmo, é preciso da informação biográfica para lermos poemas como "Água alheia" I e II, p.e., como poesias de um poeta tradutor. Ou nas sucessivas citações e alusões como à página 46, de A foto fatal, "Emily Dickinson, morri bela beleza, etc., versão 1977", Mas ao percebermos que, mesmo que sua produção poética seja volumosa, como destaca Sebastião Uchôa Leite (WANDERLEY, 2001, orelhas), a maior parte da obra poética de J.W. é exatamente tradução de outros poetas, entende-se que a figura do tradutor é fundamental na leitura de sua poética.

São identidades fixas, prefiguradas, marcadas socialmente que a voz de seus poemas assume. Uma votada ao mundo da saúde, o que "pratica a saúde dos outros", e da ciência, outra votada ao mundo da cultura e das letras. A primeira, mais que a segunda, goza de enorme prestígio social, mas ambas são remarcadas de um deslocamento para o outro, o profissional de saúde e o tradutor, tal como o professor, são profissionais de cujo ofício se realiza para o sucesso do outro, a saúde do outro, a obra do outro, a realização profissional do outro. "Ouça comigo: - o tempo das maçãs / eu tirei de um poema de onde fazendas / acordaram Dylan Thomas" ("Água alheia II", 1986, p. 91). E especialmente o tradutor usa seu esforço e talento para o brilho da obra de outro. Dentro propriamente do campo literário, o tradutor sempre será um artista do outro, um poeta da outra voz. Um nome em risco de apagamento diante do brilho da obra de outrem. A "Invisibilidade" é uma constante para quem analisa a condição do tradutor (WYLER, 2003, p. 15).

Pode-se apontar na tradução um exercício de aprendizado de escrita e do autor traduzido, mas é um exercício de ser outro também, de ser a voz de outro e outros na estranheza de outra língua. "Camaleão e Louva-Deus" como no poema de Wilbur citado acima, adaptando sua pele à floresta para tornar outra a floresta, mostrando que a folha é mais folha e o verde é mais verde.

\section{Fazendo água...}


Em Foto Fatal (1986), há o poema "Fazendo Água", poema de livro anterior Mesa/Musa (1980-85) incluído em Foto Fatal, ou ainda, de grupo de poemas anterior, em que uma profunda tensão se dá entre aquele que escreve e a tradição, entre o escritor e o conjunto de precursores. E a mesa é o primeiro objeto a surgir no poema.

Antes a mesa era grave e todos sentavam a meu lado para ver como eu escrevia.

Agora escrevo no deserto.

Não sei se tinha mais medo com eles ou se tenho mais sem eles. $(1986$, p. 88)

O centro em que gira o poema é a questão do escrever. Uma escrita ritualizada em que a mesa é componente fundamental. A escrita, como nos mostra Foucault, citando J.B. de La Salle, adquire no processo educacional da modernidade um caráter disciplinar rigoroso de docilização do corpo, em que as posturas das costas, dos ombros, dos braços e das mãos, o modo de empunhar a pena, a caneta ou lápis (depois posicionar a mão na máquina, no teclado) é fundamental ao bom desempenho da tarefa.

Uma boa caligrafia, por exemplo, supõe uma ginástica - uma rotina cujo rigoroso código abrange o corpo por inteiro do pé à extremidade do indicador. Deve-se 'manter o corpo direito, um pouco voltado e solto do lado esquerdo, e algo inclinado para frente, de maneira que, estando o cotovelo pousado sobre a mesa, o queixo possa ser apoiado na mão, a menos que o alcance da vista não o permita; a perna esquerda deve ficar um pouco mais avançada que a direita, sob a mesa. Deve-se deixar uma distância de dois dedos entre o corpo e a mesa; pois não só se escreve com mais rapidez, mas nada é mais nocivo à saúde que contrair o hábito de apoiar o estômago contra a mesa; a parte do braço esquerdo, do cotovelo até a mão, deve ser colocada sobre a mesa. O braço direito deve estar afastado do corpo cerca de três dedos, e sair aproximadamente cinco dedos da mesa, sobre a qual deve apoiar ligeiramente. O mestre ensinará aos escolares a postura que estes devem manter ao escrever, e a corrigirá seja por sinal seja de outra maneira, quando dela se afastarem'. (FOUCAULT, 2002, p. 130)

Nesse conjunto ergonômico a mesa ocupa importante papel. Sua superfície, sua altura garantem a articulação das posturas corretas. A disciplinarização do gesto de escrita reveste a gravidade da mesa do primeiro verso. E essa gravidade se reforça com a presença de outros que analisam sua escrita no decurso do próprio ato da escrita. Mas quem são esses "todos" que se "sentavam" ao lado do eu do poema, ação solidária, mas também de exame "para ver como eu escrevia". 
A estrofe se divide em duas partes simétricas de situações antagônicas. $\mathrm{Na}$ primeira parte, o ato solitário da escrita está inserido num contexto de solidariedade como se a composição fosse um gesto individual, mas cercado de cuidado coletivo, pois diante da "mesa grave", "todos sentavam a meu lado". E estavam ali para "ver como eu escrevia". A situação tem duplo significado de apoio solidário e olhar julgador, mas de toda forma inserido numa ação coletiva. A primeira situação termina com um verso em oito sílabas métricas, a segunda situação se inicia também com um octossílabo, que põe de pronto a situação oposta de agora: "Agora escrevo no deserto." É cortante o verso que marca a nova situação. Não há censura, mas também não há o acompanhamento solidário, olhar dos mestres, nem o leitor prévio... E a condição da escrita solitária põe uma nova condição de temor. "Não sei se tinha mais medo com eles ou se tenho mais sem eles". Vê-se que o olhar de quem estava ao lado era de julgador, avaliador, mestre... razão do medo primeiro, medo do erro, do vacilo, da censura dos mestres.

Mas na escrita com "eles" "todos" ao lado, apesar do medo da censura, vê-se na segunda estrofe.

Eles eram confortáveis porque diziam "é por aqui" mas eram terrificantes porque diziam "ninguém fará melhor do que nós"

Angústia da influência, o conforto e o limite do "nome do pai"? Agora se pode determinar melhor quem eram o "eles" e o "todos": o exemplo, os grandes mestres escritores, a tradição a pesar sobre o juízo do que escreve. O conforto de ser orientado, de ver um caminho e um sentido indicado por "todos eles" da tradição, mas ao mesmo tempo o fantasma do insuperável que faz, no fundo, desnecessária toda ação de uma nova escrita. Diz Harold Bloom sobre a angústia da influência:

Aquilo que dá prazer ao leitor-como-crítico pode provocar angústia no leitor-como poeta. Uma angústia que todos nós, como leitores, aprendemos a negligenciar, por nossa própria conta e risco. Essa angústia, essa modalidade de melancolia é a angústia da influência, 0 território demoníaco e obscuro que agora vamos adentrar (BLOOM, 1991, p. 56)

E, segundo Bloom, Edward Young apresentaria sua reclamação sobre os grandes "progenitores poéticos", os grandes precursores. 
Eles absorvem nossa integral atenção, prevenindo assim a mais necessária observação de nós mesmos; engendram preconceitos, que nos predispõem a um julgamento favorável de suas capacidades, mesmo às custas das nossas; e nos intimidam com todo o esplendor de sua fama (YOUNG apud BLOOM, 1991, p. 59).

Essa seria a caracterização da "angústia da influência", para vive-la e superá-la apenas os que o próprio Bloom chamará de "poetas fortes". Mas esse mal de angústia, ou ao menos seu diagnóstico, é ele mesmo datado por Bloom, se daria com Ben Johnson (1572-1637), contemporâneo de Shakespeare. Ocorreria na relação de predecessores de um príncipe a mesma responsabilidade com os poetas. O peso da responsabilidade sobre os ombros de um príncipe, "faz-se na razão direta de virtude de seus predecessores", e comparava, "aquele que sucede a um grande poeta encontrará as mesmas dificuldades" (JOHNSON, apud BLOOM, 1991, p. 60).

Parece até aqui, no poema de Jorge Wanderley, que é dessa angústia que trata. É ela que está praticamente explícita no dístico que compõe a segunda estrofe. É dela também de certa forma que Jorge Wanderley trata em texto sobre a tradução da Divina Comédia, do Inferno. Reparemos como o tópico da mesa e a presença dos escritores de outrora estão presentes no texto em que ele retrata sua própria condição no momento, escrevendo um "prefácio" para sua tradução do Inferno, da Divina Comédia.

Imagino alguém que se disponha a escrever um prefácio a alguma nova tradução de $A$ divina comédia (ou ao Inferno, tarefa ao mesmo tempo mais simples e mais complexa). Imagino que tome posição à sua mesa de trabalho (a mesa dócil, o árdego computador) cercado de livros, anotações, ideias e ansiedades. Pensa em quantos já o tentaram e em quantos se esforçaram diante das muralhas, mal encaradas como o próprio Dante, ameaçadoras como o aviso da porta infernal. Sem esperança possível, começa a escrever, movido talvez por aquelas únicas atenuantes: mudaram-se os tempos, mudaram-se as vontades. Àquele que hoje escreve lhe é agora permitido conceber as suas linhas como uma pré-estrutura, texto andaime, o que um dia será, o não ainda, o prenúncio do que em algum tempo (nunca) virá a ser, o que mais tarde (então tarde demais) se entregará à tarefa menor da consumação; de passar de potência a ato. No interior de inesperada acalmia fica então possível continuar (WANDERLEY, 2010, p. 27).

A situação de enfrentamento com o passado cultural, a descrição da situação, a tópica da mesa de trabalho sob o cerco dos anteriores, a mesa neste texto aparece como componente dócil, mas o instrumento para a escrita - "o árdego computador" surge como algo "irascível", "ardente", o medo "diante das muralhas, mal encaradas 
como o próprio Dante", a angústia, a semelhança da poesia com o texto em prosa nos parece bastar por si e ambos remetem a um diálogo com a obra de tanto sucesso de Bloom. Marco Lucchesi identifica a pertinência com a "angústia da influência" igualmente (LUCCHESI, 2010, p. 9). Se após àquele prefácio há a tradução do poema de Dante, o poema que estamos analisando também não termina nessa estrofe.

Agora ninguém aponta caminho nenhum

E nenhuma comparação me é permitida.

$\mathrm{Na}$ terceira estrofe, tem-se outro dístico que retoma a questão do deserto e do vazio em que se encontra agora, sem quem indique qualquer direção, sem a terrível comparação com os insuperáveis predecessores. Nos versos livres do poema e da frequência de versos livres deste poeta, a métrica deste dístico chama atenção, os dois têm as mesmas 13 sílabas métricas, de ritmo variável e formando um leixa pren com a forma nenhum-nenhuma. O primeiro verso tem acentuação forte na $5^{\mathrm{a}}, 10^{\mathrm{a}}$ e $13^{\mathrm{a}}$. $\mathrm{O}$ eixo do leixa-pren atrai a pausa forte para mais ao início do segundo verso, por isso a acentuação do segundo é na $3^{\mathrm{a}}$, na $8^{\mathrm{a}}$ e $13^{\mathrm{a}}$. Mas esse malabarismo em versos bárbaros aponta também para essa quebra com os mestres predecessores, por esse espaço, lugar deserto do "nenhum-nenhuma". Não são redondilhas, não são decassílabos, não são alexandrinos, são um formato de versos sem predecessores fortes demarcados. No contexto contemporâneo de tantos mestres passados do verso livre, também não são em versos livres. São em versos bárbaros, um tanto fora, portanto, da tradição do verso de metrificação lírica rigorosa e da tradição moderna do verso livre.

Cabe perguntar, houve uma superação da angústia da influência? Estaria o poeta nessa posição do poeta formulador de um novo lugar e voz de poesia, um novo ancestral ou um poeta em "estado de Satan" como expõe Bloom? "Pois Satan é uma absoluta ou pura consciência de si, compelida a admitir sua aliança íntima com a opacidade" (1991, p. 64). Pura consciência de si esse estado sem ninguém, sem caminho apontado e sem comparação: o deserto. Mas o que seria essa opacidade? "O estado de Satan é, portanto, uma constante consciência do dualismo, da condição de se ver amarrado à finitude, não só no espaço (no corpo), mas na cronologia do tempo também" (1991, p. 64). Estado de diferença pura da consciência de si, que implica também esta consciência de seus limites, a partir das intuições puras a priori do espaço e do tempo, do caminho a ser trilhado só, e sem comparação possível com qualquer 
outro. "Ser puro espírito, e todavia reconhecer, em si mesmo, o limite de opacidade; afirmar uma existência cuja origem se perde antes da Criação/Queda, e todavia ser constrangido a .submeter-se ao número, ao peso e à medida:" (1991, p. 64) É preciso evocar a antiguidade dos mitos para falar do incomparável e dela trazer a condição desse poeta que rouba de seu Original Supremo para ser também agora um precursor: "esta é a situação de todo poeta forte, de toda imaginação capaz, quando se confronta com o universo da poesia, com as palavras que foram e que serão, o terrivel esplendor da herança cultural" (1991, p. 64). Aqui se vê a semelhança do tratamento da herança cultural como "terrivel", neste trecho de Bloom, e "terrificantes", da segunda estrofe do poema. E assim a "angústia" em nossos dias se torna ainda mais desesperadora do que no tempo de Milton (século XVIII) ou de Wordsworth (século XIX), pois maior o acúmulo.

Mas o poema ainda não se encerrou.

A próxima estrofe do poema, revira a tensão da "angústia da influência" de Bloom pelo avesso e a esvazia, entregando/transferindo àquele que escreve a dimensão própria de como se relaciona com a tradição e se posiciona na escrita. A quarta estrofe quebra o campo das preocupações teóricas de Bloom, e as realoca num campo mais solidário, inevitavelmente solidário do homem em sua tribo, vivente coletivo. "Eu", mas sem o individualismo moderno?

\footnotetext{
Ou então tudo isto é pura conversa fiada e eu sempre estive só no meio deles e eles estão aqui ao meu lado, respeitosos. Conversa ou não, nossas relações são as mesmas
}

Fino humor, a angústia da influência é passada em conversa-fiada. O ensinamento de T.S. Eliot parece mais vivo, mais pertinente aqui. "Nenhum poeta, nenhum artista, tem sua significação completa sozinho" (ELIOT, 1989, p. 39). No ato de escrever, no existir, na recepção leitora, inevitavelmente se está no meio de outros. Independentemente de como se estabeleça essa relação com os outros, com o passado e o meio, "conversa ou não" ali estará, simultaneamente "só" e "no meio deles". E "eles" não mais estarão como mestres ou avaliadores, simplesmente estão ao lado "respeitosos". No ensaio "Tradição e talento individual", de 1917, Eliot constrói uma imagem de arte, de poesia em consonância com a tradição e da tradição em rearranjo 
com o novo. Começa para isso por afastar o preconceito do individualismo existente quando buscamos na obra de um poeta aquilo que nela menos se assemelha a qualquer outra obra. E ao assim procedermos buscamos em tais trechos ou aspectos aquilo que é idiossincrático, essencial num homem.

Ao contrário, se nos aproximarmos de um poeta sem esse preconceito, poderemos amiúde descobrir que não apenas o melhor, mas também as passagens mais individuais de sua obra podem ser aquelas em que os poetas mortos, seus ancestrais, revelam mais vigorosamente sua imortalidade. (ELIOT, 1989, p. 38).

A seguir, Eliot ressalta que a tradição não pode ser algo simplesmente a ser seguido, algo inercial. Pelo contrário, a relação com a tradição é mais complexa e ampla. "Ela não pode ser herdada, e se alguém a deseja, deve conquistá-la através de um grande esforço" (p. 38). O poeta precisa apreender o sentido histórico de seu fazer e é aqui que podemos compreender melhor o "eles" que acompanham o "eu" desde o início do poema.

O sentido histórico leva um homem a escrever não somente com a própria geração a que pertence seus ossos, mas com um sentimento de que toda a literatura europeia desde Homero e, nela incluída, toda a literatura de seu próprio país têm uma existência simultânea e constituem uma ordem simultânea. Esse sentimento histórico, que é o sentido tanto do atemporal quanto do temporal e do atemporal e do temporal reunidos, é que torna um escritor tradicional. E é isso que, ao mesmo tempo, faz com que um escritor se torne mais agudamente consciente de seu lugar no tempo, de sua própria contemporaneidade (ELIOT, 1989, p. 39).

Fazem sentido as séries de nomes de escritores evocados em vários poemas e que, dissemos antes, busca compor um plano de transcendência da poesia em que o "eu dos poemas" parece querer submergir em meio. Um jogo de despersonalização e de construção de uma subjetividade, que não se dirá esvaziada, nem plural, e sim mais solidária. Imbuída do coletivo da tradição conquistada pelo estudioso poeta de seu fazer, pelo professor e, sobretudo, em Jorge Wanderley, pela figura do tradutor, esse agente do outro, esse locutor do "eles".

Esses "eles" da tradição são "respeitosos" por esses motivos ao menos: um, o eu do poema conquistou aquela herança e, dois, porque o passado não apenas dita para o presente seus modos e julgamentos é igualmente transformado pelo presente, como ressalta Eliot, nenhum poeta tem sua significação de modo isolado, ele 
precisa ser pensado por uma espécie de conjunto trazido pelo passado. "Não se pode estimá-lo em si; é preciso situá-lo, para contraste e comparação, entre os mortos. (...) Os monumentos existentes formam uma ordem ideal entre si, e esta só se modifica pelo aparecimento de uma nova (realmente nova) obra entre eles" (ELIOT, 1989, p. 39).

e continua havendo por aí a fora um deserto para alguns um terror para outros e esta minha naturalidade de barqueiro que vê a água se acumulando no fundo do barco.

É com essa nova concepção de eu, mais solidária, que o poeta pode se dizer equidistante dos que se veem num deserto ou diante do terror dos olhares judiciosos. "Fazer água" é uma expressão náutica, a água que se acumula no fundo do barco, vista com naturalidade pelo barqueiro, diz do convívio do barqueiro com seu ofício, diz da invasão do tempo que se acumula e prenuncia o fim. Deslocada de seu campo de origem, fazer água é também uma expressão feliz, de água como fonte de vida. Um poço que faz água é uma benção. Mas ainda assim a água é o que tudo dilui, "a água não tem cabelo" diz um dito popular sobre o perigo de se afogar, nela não há onde se agarrar e a tudo ela absorve, engole. Indiferenciação. A naturalidade do barqueiro vendo a água se acumular no fundo do barco, é também uma metáfora para o homem sábio que observa a passagem do tempo e vê que aquele acúmulo inevitável marca também as riquezas e limitações do barco. Seu tempo conquistado e seu tempo que finda. Ao fim, Fazendo água, traz-nos as palavras de João Alexandre Barbosa ao apresentar em panorâmica a trajetória poética de Jorge Wanderley: "É o acoplamento amadurecido do leitor de toda uma enorme tradição lírica ao poeta que até então se debatera por entre as perigosas urgências da expressão pessoal pautadas por aquela mesma tradição" (BARBOSA, 2001, p. 19).

\section{A interioridade de espera: a morte}

A iminência da morte forma uma linha de força na poesia de Jorge Wanderley, a morte próxima pelos enfartos, um aos 41 anos, segundo o poema "Prefácio", de Coração à parte (WANDERLEY, 1986, p. 43), por exemplo... mas é sobretudo a morte iminente de todos, para todos que se manifesta e indaga nos poemas, como no livro 
Anjo Novo, à página 18, em que da situação mais prosaica, cotidiana, do fumante de cachimbo resolvendo que fumo escolher surge a questão da unidade e presença constante da morte, ou de uma dimensão metafísica que atravessa os momentos sem nos darmos conta.

O que estava na porta da loja
dois anos atrás
vacilando entre dois fumos

O pronome "o", que abre o poema, assume a função especular com a voz que se manifesta na construção do poema, "aquele" irá se tornando gradativamente "eu". A escolha do verbo "vacilar" aqui é de enorme importância, a situação de escolha, de controle racional, de decisão, da positividade do sujeito cognoscente é trazida para o campo semântico não apenas da dúvida, mas da indefinição, da demora, da perda de tempo, do equívoco em potencial, do erro iminente. Essa situação será mais aprofundada na estrofe seguinte, quando o verbo antes no gerúndio assume a forma substantiva.

o que estava em outra
dez anos atrás
noutro vacilo

De "vacilando" a "vacilo", o sentido migra da potência para o ato. O erro se consolida pela afirmação do passado "dez anos atrás", cujo resultado da experiência já fora vivido. Porque "vacilo", no linguajar contemporâneo, é ter dado "um mole" para o azar, é ter comprometido alguém ou alguma situação com sua atuação ou falta dela.

E se as duas primeiras estrofes encerram em si todo um período de significação, um período gramatical, a terceira não o faz. Ela presentifica na série do tempo de vida a mesma situação de "vacilação" e na negatividade do vacilo a identidade do mesmo pela síntese de memória e constatação. A mesmificação pelo inexato, ineficaz, pelo erro, pela perda do tempo de vida que se repete.

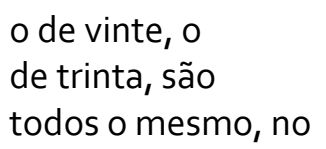

Nas duas primeiras estrofes, cada verso encerra em si uma função sintática, o corte dos versos recai oportunamente sobre uma pausa um tanto natural ao falante em sua pontuação oral, isso não ocorre nesta terceira, o cavalgamento dos versos é brutal, 
nenhum verso se completa num mínimo sintático como nas estrofes anteriores. Há incompletude e sobra. E surge a pontuação gráfica que não há nas demais estrofes para reforçar ainda mais a quebra da continuidade, para separar o sujeito composto do verbo (erro na gramática normativa), enquanto o enjambement desarticula o predicativo e lança uma preposição e um artigo como uma ponta sobre o nada em busca/espera da quarta estrofe.

mesmo limbo
esperando
trombetas

A quarta estrofe é quase que de uma palavra a cada verso, e "o mesmo" como personagem identitária através do tempo se encontra "no mesmo" lugar sempre, e esse lugar é o limbo. No dicionário Houaiss, a primeira significação para a palavra "limbo" remonta à teologia cristã, a ela voltaremos; a segunda, em sentido figurado, também é muito pertinente para a leitura deste poema: "estado de indecisão, incerteza, indefinição", como se vê o lugar retoma o campo semântico do "vacilando" da primeira estrofe. A terceira significação, igualmente figurada e informal, é a do "depósito de coisas inúteis" (HOUAISS, 2001, p. 1758), que remonta à mesma negatividade realizada (in ato) do "vacilo" da segunda estrofe. Mas o estado de indefinição e o depósito de coisas inúteis são significações figuradas advindas da primeira, a teológica. Na teologia cristã, o Limbo, do latim limbu (orla), é o lugar onde permanecem as almas justas que não cometeram pecado mortal, mas que não se redimiram do pecado original pelo batismo (AZEVEDO, 2002, p. 223). Com isso abria-se um lugar na cosmologia cristã para todos os justos que viveram antes do cristianismo, assim como para os justos de povos não convertidos. Mas uma possibilidade havia para que essas almas no limbo ascendessem ao céu: Cristo um dia as libertaria.

De volta à quarta estrofe do poema, vê-se que a imagem de um juízo final em que retornaria o Cristo para redimi-lo está presente. Em poucas palavras um cenário teológico complexo se mostra, "no / mesmo limbo / esperando / trombetas". O verbo retorna ao presente indefinido do gerúndio numa palavra que remarca a incapacidade de definir "esperando", aprofundando metafisicamente a marca de indefinição do "vacilando" da primeira estrofe, quando o verbo ainda se encontrava na esfera do controle racional do sujeito em ação. Agora o sujeito se desfaz de qualquer atividade e 
assume a pura passividade da espera. E se na primeira estrofe a cadeia de sentidos se dava no campo da objetividade empírica, cotidiana, dos afazeres mais banais, na quarta e última, o campo é metafísico, religioso. E toda concepção de poder do indivíduo se esvazia diante da potência das trombetas que anunciarão o Juízo Final e a sua redenção dessa condição indefinida e negativa em que sempre esteve. Revista a primeira estrofe a partir da leitura integral do poema, a palavra fumos, "vacilando entre dois fumos", se torna também carregada de sentidos múltiplos, indeterminados, perde a sua natureza banal e adquire a possibilidade de ser lida como representação de um mundo onde tudo é fumaça, nada é concreto e verdadeiramente real.

Poema, portanto, do esvaziamento da figura da subjetividade individualista com sua racionalidade soberana e das pretensões de conhecimento real sobre a natureza da vida e do mundo. Poema que trata daquilo que Maurice Blanchot chamou de "interioridade de espera", e que Deleuze ao ler Foucault ressalta, dentre as dobras que nos constituem sujeitos, como a quarta dobra, a dobra da relação que se traça com a morte: "é dela que o sujeito espera, de diversos modos, a imortalidade, ou a eternidade, a salvação, a liberdade, a morte, o desprendimento..." (DELEUZE, 1988, p. 112). Poema do desprendimento.

\section{Re-Fratriado}

Numa construção de subjetivação que se faz "fazendo água" na pluralidade. Poética de profunda vinculação a uma ética da simplicidade, a uma submersão do eu num modo de subjetividade mais coletivo, mais integrador, que o poema "Fratria", de $O$ agente infiltrado e outros poemas (1999), bem apresenta numa narrativa clara. E claramente oriunda do cotidiano das grandes cidades.

Ontem na rua, eu os vi, amontoados, e casuais, nos trapos, na fuligem que invadia suas peles e nas úlceras e curativos nos lábios rotos por socos e escorbuto; amontoados e naturais, passando ora a garrafa ora um pão seco e eram homens e eram mulheres, que falavam, que se entendiam, e um deles mais que os outros 
pontificava, e maximoso dava o tom

de uma filosofia já perdida

e mágica e infalível

a julgar pela voz com que falava.

(2001, p. 198)

O poema evoca o poema "O bicho", de Manuel Bandeira. A referência ao "ontem", o verbo ver e a temática sugerem a aproximação, "Ontem na rua, eu os vi". O começo do poema de Bandeira é assim: "Vi ontem um bicho / Na imundície do pátio / Catando comida entre os detritos" (BANDEIRA, 1980, p. 179). A forma pronominal "os" logo ao início do poema de Jorge Wanderley supõe um conhecimento prévio da existência deles e, feita a vinculação com o poema de Bandeira, ao "bicho". A condição de "amontoados" já diz da condição de destrato, descaso daqueles. E o quadro de miséria e insalubridade se intensifica. Depois de amontoados virá, "e casuais, nos trapos, na fuligem/ que invadia suas peles e nas úlceras", não é uma condição temporária é um modo permanente, a sujeira já entranhada, as feridas já ulceradas. Em que alguma intervenção civilizada se fez nos curativos, mas tudo tomado pela sujeira pesada em fuligem assim como há marcas de violências sofridas, e fome a gerar escorbuto "e curativos nos lábios rotos / por socos e escorbuto, amontoados", em que retorna o adjetivo amontoados para indicar a condição do grupo, mas pela quebra do verso a indicar também o amontoado de males a romper os lábios. Porque o cavalgamento cinde a dupla de adjetivos que apontam para dois pesos distintos: "amontoados" possui uma carga negativa do desarrumado, do sem regra, enquanto o adjetivo seguinte "e naturais" abranda a carga negativa e recoloca a cena num contexto de "normalidade", de adequação a uma matriz de regras. A quebra da dupla de adjetivos é de enorme maestria na composição do poema. A partir da introdução do adjetivo "naturais" uma organização social começa a se mostrar, e, do grupo de miseráveis, a solidariedade desponta. "e naturais, passando ora a garrafa / ora um pão seco e eram homens / e eram mulheres, que falavam, / que se entendiam". A descrição sai do campo do "bicho" para o da comunidade humana pela diversidade identificada, "eram homens", "e eram mulheres", pela troca, "passando ora a garrafa / ora um pão seco", pela palavra, "que falavam", e pelo entendimento.

Nessa comunidade de rotos, organização social de miseráveis, uma outra marca civilizacional desponta: a liderança. Um filosofo basileus surge das expressões 
"pontificar" e "maximoso". "Pontificar" é de etimologia eclesiástica, "ETIM pontífice + ar; prov. por infl. do fr. pontifier (s.XV) 'elevar à dignidade de papa" (HOUAISS, p. 2258). Suas significações mais literais são de "oficiar na qualidade de pontífice"; "celebrar missa com a capa pontificial"; e figurativamente "falar ou escrever em tom categórico". Da quantidade de vocábulos que poderia ser escolhido dentro do paradigma do "dizer", o poeta foi buscar aquele que caracteriza a mais suma nobreza para atribuir ao líder daquele grupo de mendigos. Ao que soma o neologismo "maximoso", que não apenas aponta para o superior como trás profundas ressonâncias de latim, a remarcar o aspecto solene e sagrado, de missa, de palavra papal, de condição especial da circunstância da fala. O sagrado do tom ressoa a antiguidade de uma filosofia secreta, pois mágica e infalível, sabedoria de um druida, apóstolo ou profeta.

A segunda estrofe, um terceto, marca a transição de uma voz soberana "que falava" ao fim da primeira estrofe para uma ação coletiva "conversavam".

$$
\begin{aligned}
& \text { Conversavam, os cinco ou seis, talvez, } \\
& \text { indistinguíveis, todos, forma igual, } \\
& \text { e iguais murmúrios e grunhidos. }
\end{aligned}
$$

Tem-se um quiasmo em antítese a cruzar a estrofe, ela abre com conversavam, comunicação humana e encerra com "grunhidos" voltando à condição de bicho sugerida no início do poema. A afirmação que abre a estrofe, "conversavam", é especificada em número, mas de modo impreciso, "os cinco ou seis", e o advérbio "talvez" que termina o verso torna vaga a certeza tanto da afirmativa inicial quanto da possibilidade de precisão do número. E há mais ainda nessa estrofe a chamar atenção. O segundo verso é inteiramente composto dentro de um mesmo campo paradigmático de significação que se repete a cada vírgula. Constrói o reino do indistinto, do sem delineamento de individuação, do comunal acima do indivíduo: o adjetivo "indistinguíveis", o pronome indefinido "todos", e o sintagma "forma igual". Reino que se prolonga ainda no terceiro verso para dizer das manifestações de expressão daqueles "indistinguíveis": "e iguais murmúrios e grunhidos", como se formassem uma matilha.

A indicar o tempo que se torna mais intenso, os instantes fatais, as estrofes se tornam mais curtas, a tensão aumenta. Após a longa estrofe inicial de 14 versos, há três estrofes breves um terceto e dois dísticos. A menor delas, o primeiro dos dísticos, com o menor verso do poema, marca o instante de maior tensão. 
Mas um deles

ergueu a cabeça e me encarou

É um instante chave, daquele grupo de "indistinguíveis" se destaca um que o encara. Uma agressão estaria para acontecer? Estaria sendo marcado para um ataque futuro? É essa encarada significativa de hostilização permanente?

Não seria exagero a aproximação com o poema macabro de Baudelaire, Les septe vieillards, em que é descrita uma névoa suja e amarelada que encobre as ruas da cidade em plena manhã, criando um ambiente de mistério, a rua se transformando como em dois cais de um rio em cheia. E enquanto o eu do poema, nervos aguçados, discute com seu espírito andando por ruas em que o som dos carroções pesados ecoa, surge de súbito um velho mendigo em cujos olhos luziam a maldade. A barba de longos pelos a parecer uma espada torna ainda mais ameaçadora a descrição da figura. E logo que passa esse, outro "igual", "nenhum traço o distinguia, vindo do mesmo inferno", "gêmeo centenário". Um traço estético se destaca, a voz do poema os define como "espectros barrocos". Essa concepção pejorativa do barroco era a dominante à época de Baudelaire: como o feio, o desforme, o mal acabado e impuro

Son pareil le suivait: barbe, oeil, dos, baton, loques, Nul trait ne distinguait, du même enfer venu, Ce jumeau centenaire, et ces spectres baroques Marchaient du même pas vers un but inconnu.

À quel complot infâme étais-je donc en butte, Ou quel méchant hasard ainsi m'humiliait?

Car je comptai sept fois, de minute em minute, Ce sinistre vieillard qui se multipliait!

(BAUDELAIRE, 1999, p. 65)

No fim do poema de Baudelaire o narrador da cena se apressa e se refugia por trás de uma porta, para dentro de um prédio. Uma vez protegido fisicamente, é sua razão, após aquela experiência estranha, que se vê em perigo. A imagem do "gabarre" (barco de transporte de carga) sob a tempestade monstruosa de um mar sem bordas que the rompe a quilha, arranca a mastreação e as cordas, no qual a razão tenta manter o controle em vão. E sua alma dança e dança. Fecha o poema com a internalização da estranha ocorrência no eu que narra.

Vainement ma raison voulait prendre la barre;

La tempête en jouant déroutait ses efforts,

Et mon âme dansait, dansait, vieille gabarre 
Sans mats, sur une mer monstruese et sans bords!

Aqui, no poema de Jorge Wanderley, não há o clima misterioso, não é preciso para produzir a sensação de medo na cidade brasileira contemporânea. O bando não é uma sucessão de indistintos maltrapilhos fantasmagóricos, mas um grupo bastante real, simultâneo, organizado. Como se pode ver no dístico seguinte, a leitura da hostilização ainda se aprofunda mais: "Fui reconhecido". Que pode significar esse reconhecimento? Para além da "encarada" identificadora que falamos há pouco, o reconhecimento torna a situação mais tensa. Reconhecer redobra o tempo presente para um passado em que houve o conhecer. Que estaria em jogo? O refúgio para o narrador também se dá de modo diferente, não abrindo rapidamente uma porta e se metendo para dentro, preservando sua individualidade. Mas buscando também para si o lugar da indiferenciação, do cardume humano da "multidão". Não o fechamento num dentro, mas o exílio num fora constituído de muitos corpos. "'Fui reconhecido', pensei comigo, / Enquanto me afastava na direção da multidão".

Há também uma internalização no eu que narra a situação: "pensei comigo". Mas não será nesta que se encerrará o poema.

A última estrofe recupera um pouco de tamanho, um quarteto em que os versos se tornam longos novamente. O tempo se distensiona, o ritmo (batimento cardíaco?) se alonga novamente.

\footnotetext{
Ele me encarou como se perguntasse "Que faz você aí, no meio dos limpos? No meio dos brancos? No meio dos outros?" E concluísse: "Você sabe que seu lugar é aqui."
}

Ainda que por suposição, "Ele me encarou como se perguntasse", ocorre a internalização do outro e um diálogo intersubjetivo. No entanto esse diálogo internalizado fala muito mais do pertencimento a um grupo, a "Fratria" que intitula o poema, do que de uma situação individual. É esse reconhecimento de pertencer à minoria que produz a oposição da fraternidade à multidão. Essa fraternidade sagrada de auto-excluídos dos modos da maioria, da multidão. Aqueles limpos, brancos e outros, que demarcam um lá, não se singularizam como um conjunto de escritores e artistas se singularizam por valores próprios das artes aqui. 


\section{Conclusão em três pontos}

Um. O exercício constante da poesia em traduções e as muitas citações e referências na poesia de J.W. ele mesmo, fundam metaforicamente uma espécie de campo transcendental kantiano da poesia. Deleuze começa por explicar o transcendental da seguinte maneira. "Não basta constatarmos que, de fato temos representações a priori. É necessário ainda que expliquemos por que e como essas representações se aplicam, necessariamente, à experiência, embora não derivem dela" (DELEUZE, 1986, p. 27). O que é esse externo, esse para além da experiência que a rege e torna possível? É esse o "transcendental Kantiano" que aqui pensaremos metaforicamente. Campo do fundamento, mas fundamento imanente: "Transcendental designa o princípio em virtude do qual a experiência é necessariamente submetida às nossas representações a priori" (1986, p. 27). É exatamente o que a poesia de Jorge Wanderley busca fazer com as séries de nomesobras, fundar um "transcendental", um campo de imanência da poesia. Patamar de onde a poesia pode ser pensada em sua espécie e em sua singularidade. Somente com as séries de poetas se pode empiricamente conhecer a poesia e somente pela experiência serial da poesia se pode ter a experiência da poesia que não está entre aquelas ou de nenhum daqueles. Assim como saber reconhecer o que seja a poesia, mesmo que uma dada experiência seja nova.

Dois. O biografismo, a tendência solipsista da literatura contemporânea apontada por Todorov, é marca daquela estratégia do poder nas sociedades modernas de fazer o sujeito falar de si, mostrar-se incessantemente, estar sob o panoptismo como nos faz ver Foucault, em que o indivíduo fala de si pensando estar se libertando, mas na verdade apenas cumpre as exigências de um poder disciplinar. A poesia de Jorge Wanderley traz uma recusa à interiorização do sujeito e ao espessamento deste por uma reincidência constante do discurso autorreferente. Se a subjetividade se faz por múltiplas dobras, como nos diz Deleuze, a poética de Jorge Wanderley faz e refaz dobraduras por uma extimidade do múltiplo, por um deslizar da palavra sempre para formar algo que se afunde na tradição, no outro. Ou como disse Silviano Santiago um 
poeta da desocupação, do despojamento (SANTIAGO, 1987, p. 3-6). Um constante "fazer água" do campo transcendental da poesia por dentro do barco de sua própria.

Três. Contemporâneo? Ao se falar em "tendências contemporâneas da poesia brasileira" pode-se perguntar sobre a pertinência deste artigo para tratar do contemporâneo. Pois o autor de que tratamos neste texto faleceu em 12 de dezembro de 1999, ficou no século XX. É contemporâneo para nós adentrando a segunda década do século em que ele não viveu? Já é bastante conhecida a afirmação de Agamben do contemporâneo através da noção nietzscheana de intempestivo (AGAMBEN, 2009, p. 58). Mas nos parece que em certas situações extremas esse intempestivo se mostra como a emergência do tempo. Se mostra como a claridade que nos resgatará de nossos próprios perigos. Assim, inicialmente pensamos, seria necessária uma justificativa a essa inserção do poeta Jorge Wanderley como autor contemporâneo, 20 anos após sua morte. Mas, entre o início da produção deste artigo em janeiro de 2020 e o momento de sua conclusão, um acontecimento de grande repercussão, do qual ainda não sabemos nem mesmo os seus mais evidentes efeitos globais, atingiu o mundo. $A$ pandemia de COVID19, pôs em xeque certos modelos das sociedades pós-industriais, da cultura do descartável e do individualismo, resultou na valorização sobremodo da questão que buscamos ressaltar na poética de Jorge Wanderley, esse mestre em humildade, esse constante aprendiz da voz do outro.

A urgência de novos modos de estarmos no planeta passa por novas formas de subjetivação. Essa urgência por profundas transformações atravessa diversas áreas de pensamento, em Economia Donut, a economista Kate Raworth, procura redefinir modelos para a economia mundial que superem os problemas insolúveis a que os atuais paradigmas de pensamento econômico atiram o mundo.

O que é exatamente o Donut? Em poucas palavras, é uma bússola radicalmente nova para guiar a humanidade neste século. E aponta na direção de um futuro capaz de prover as necessidades de cada pessoa e ao mesmo tempo salvaguardar o mundo vivo do qual todos nós dependemos. Abaixo do alicerce social do Donut encontram-se déficits no bem-estar humano, enfrentados por aqueles que carecem de bens essenciais para a vida, como alimento, educação e moradia. Para além do teto ecológico, encontra-se um excesso de pressão nos sistemas geradores de vida da Terra, como mudanças climáticas, acidificação dos oceanos e poluição química. Mas entre esses dois conjuntos de limites existe um ponto ideal - com a forma inequívoca de um Donut - que é um espaço ao mesmo tempo ecologicamente 
seguro e socialmente justo para a humanidade. A tarefa do século XXI é sem precedentes: trazer toda a humanidade para esse lugar seguro e justo (RAWORTH, 2019, p. 49).

\section{Referências Bibliográficas}

AGAMBEN, Giorgio. O que é o contemporâneo? e outros ensaios. Tradução de Vinícius Nicastro Honesko. Chapecó, SC: Argos, 2009.

ALIGHIERI, Dante. A divina comédia: Inferno. Tradução e comentário sobre a tradução de Jorge Wanderley. Organização e edição Márcia Cavendish Wanderley. Prefácio e preparação de originais Marco Lucchesi. São Paulo: Abril, 2010. (Clássicos Abril Coleções; v.6)

AZEVEDO, Antonio Carlos do Amaral; GEIGER, Paulo. Dicionário Histórico de Religiões. Rio de Janeiro: Nova Fronteira, 2002.

BANDEIRA, Manuel. Estrela da vida inteira. 8.ed. Rio de Janeiro: José Olympio, 1980.

BARBOSA, João Alexandre. Réquiem para Jorge Wanderley. In: Antologia poética. Organização Márcia Wanderley. Prefácio de João Alexandre Barbosa. Cotia, SP: Ateliê Editorial, 2001.

BAUDELAIRE, Charles. Oeuvres complètes. Preface de Claude Roy. Notices et notes de Michel Jamet. 8. Reimp. Paris: Robert Laffont, 1999.

BLOOM, Harold. A angústia da influência: uma teoria da poesia. Tradução Arthur Nestrovski. Rio de Janeiro: Imago, 1991.

DELEUZE, Gilles. Para ler Kant. Tradução de Sônia Dantas Pinto Guimarães. 2.ed. Rio de Janeiro: Francisco Alves, 1986.

DELEUZE, Gilles. Foucault. São Paulo: Brasiliense, 1988.

ELIOT, T.S. Tradição e talento individual. In: . Ensaios. Tradução Ivan Junqueira. São Paulo: Art Editora, 1989.

FOUCAULT, Michel. Vigiar e punir. Tradução de Raquel Ramalhete. 25. Ed. Petrópolis, RJ: Vozes, 2002. [1975]

FOUCAULT, Michel. O nascimento da clínica. Tradução de Roberto Machado. 5.ed. Rio de Janeiro: Forense Universitária, 2003. [1963; 1972]

HOUAISS, Antônio; VILLAR, Mauro de Salles. Dicionário Houaiss da Língua Portuguesa. Rio de Janeiro: Objetiva, 2001. 
LUCCHESI, Marco. Harmonia e claridade. In: ALIGHIERI, Dante. A divina comédia: Inferno. Tradução de Jorge Wanderley. São Paulo: Abril, 2010. p. 7-26.

RAWORTH, Kate. Economia Donut: uma alternativa ao crescimento a qualquer custo. Tradução George Schlesinger. Rio de Janeiro: Zahar, 2019.

SANTIAGO, Silviano. Prefácio. In: WANDERLEY, Jorge. Anjo novo. Rio de Janeiro: Taurus-Timbre, 1987. P. 3-6.

SHAKESPEARE, William. Sonetos. Tradução e notas de Jorge Wanderley. Rio de Janeiro: Civilização Brasileira, 1991.

TODOROV, Tzvetan. Poderes da poesia. In: CÍCERO, Antonio (org.) Forma e sentido contemporâneo: poesia. Rio de Janeiro: EdUERJ, 2012.

WANDERLEY, Jorge. Antologia poética. Organização Márcia Wanderley. Prefácio de João Alexandre Barbosa. Cotia, SP: Ateliê Editorial, 2001.

WANDERLEY, Jorge. Manias de agora. Rio de Janeiro: Topbooks, 1995.

WANDERLEY, Jorge. Arquivo/Ensaio Jorge Wanderley. São Paulo: EDUSP, 1994.

WANDERLEY, Jorge. Homenagem: dez sonetos de Jorge Wanderley. Rio de Janeiro: UERJ, 1992.

WANDERLEY, Jorge. Anjo novo. Prefácio de Silviano Santiago. Rio de Janeiro: TaurusTimbre, 1987.

WANDERLEY, Jorge. A foto fatal. Rio de Janeiro: Taurus, 1986.

WILBUR, Richard. "The Beautiful changes" / O belo se transforma. Tradução de Jorge Wanderley. In: KEYS, Kerry Shawn (org.). Quingumbo: nova poesia norte-americana. São Paulo: Escrita, 1980. p. 54-55.

WYLER, Lia. Línguas, poetas e bacharéis: uma crônica da tradução no Brasil. Rio de Janeiro: Rocco, 2003.

\footnotetext{
'Atualmente, é professor associado na Faculdade de Letras da UFRRJ, leciona também no mestrado profissional em Letras.

E.mail: mcnqsofocles@gmail.com
} 